\section{MANAJEMEN PROGRAM PELATIHAN SENI TRADISIONAL PADA SANGGAR SENI SEKAR WIJAYA KUSUMA SEBAGAI UPAYA PEMBERDAYAAN MASYARAKAT}

\section{Pujiwiyana}

Fakultas Bahasa dan Seni Universitas Negeri Yogyakarta

\section{Abstract}

The construction of traditional art in society may function as: a religious, educative and social integration enforcer, entertainment, and occupation. Thus, the activity of traditional art construction is also an effort of society outsourcing. For achieving this purpose it needs the implementation of a strategic program management. By the implementation of this program hopefully the entire activity of art construction in traditional gallery can be designed and conducted appropriately. In so doing, the entire program can be evaluated kindly, and the result of activity can be quantified. If all this is achieved, traditional art can be a focal point for social interaction, society involvement and wide-based participation and becomes an important process in society outsourcing in social, economic and political fields.

Keyword: program management, society outsourcing

\section{PENDAHULUAN}

Sanggar seni tradisional Sekar Wijaya Kusuma adalah merupakan wadah aktifitas kelompok masyarakat tradisional yang berada di Padukuhan Grogol, Desa Margodadi, Kecamatan Seyegan, Kabupaten Sleman. Kegiatan kelompok masyarakat tersebut merupakan aktifitas pembinaan seni tradisonal yang dipimpin oleh Bapak Sancoko, S.Pd. Adapun aktifitas pembinaan seni yang diselenggarakan pada sanggar tersebut adalah: wayang kulit, wayang orang, jathilan, dan shalawatan haddrah.

Aktifitas kebudayaan yang berakar pada seni tradisional sesungguhnya adalah usaha pewarisan nilai dari suatu generasi kepada generasi berikutnya. Sehingga interaksi yang terjadi dalam aktifitas seni tradisional merupakan kegiatan belajar, dimana dalam aktifitas tersebut akan terjadi terjadi dialog antara kelompok masyarakat yang berada di dalam habitat kesenian tersebut. Dalam dialog dimungkinkan terjadi suatu proses identifikasi terhadap masalah-masalah yang dihadapi, sehingga kelompok masyarakat tersebut akan berusaha mencar solusi dalam rangka pemecahan masalah-masalah yang dihadapi, dan pada akhirnya secara mandiri mampu meningkatkan harkat dan martabat kelompok masyarakat tersebut.

Setiap kelompok masyarakat memiliki aktifits kesenian, karena kehidupan manusia bukan sekedar terbatas ada kebutuhan fisik atau material, akan tetapi juga kebutuhan yang terkait dengan rasa ingin tahu atau kecerdasan, serta kebutuhan akan keindahan dan spiritual. Dalam kehidupan kelompok masyarakat tradisional, manusia bekerja untuk memenuhi kebutuhan ekonomi dengan pekerjaan bertani di tanah pertanian, atau mencari hasil hutan. Sementara dalam masayarakat modern manusia cenderung lebih banyak bekerja di sektor industri, perkantoran dan perdagangan dalam rangka memenuhi kebutuhan ekonominya. Apapun yang dilakukan manusia dalam aktifitas sehari-hari sesungguhnya adalah aktifitas belajar, termasuk aktifitas kesenian yang ada pada masyarakat tradisional.

Ketika manusia melakukan aktifitas bekerja, mereka juga mengembangkan pengetahuan dan ketrampilan untuk meningkatkan produktifitas kerja, dan bahkan juga mengembangkan rasa keindahan. Misalnya seorang petani yang bekerja mengolah tanah pertanian, mereka pada waktu yang sama juga belajar atau mengembangkan pengetahuan tentang mengolah tanah, dan sekaligus juga mengembangkan kemampuan seninya, sebab mengolah tanah juga memiliki dimensi keindahan. Kegiatan belajar dan seni pada kelompok masyarakat tradisional dapat juga dilakukan dalam bentuk kegiatan yang lebih khusus, yaitu sebagai kegiatan untuk mengisi waktu luang. Para petani pada waktu tidak bekerja di sawah atau ladang, pada saat-saat tertentu meeeka melakukan kegiatan berkesenian seperti bermain musik (karawitan), menari atu membuat kerajinan tangan yang lain.

Seni tradisional merupakan kegiatan seni yang tumbuh dan berkembang di masyarakat yang umumya terkait adat istiadat dan nilai-nilai yang berkembang pada kelompok masyarakat tersebut. Seni tradisional umumnya merupakan kegiatan seni yang memberikan hiburan bagi kehidupan lokal dan dilestarikan oleh tokoh masyarakat setempat. Sebagian besar budaya tradisional, berkembang dan dilestarikan dari "tradisi lisan". Tradisi yang demikian disebut folklor, ("folk" = rakyat; "lor" = unsur-unsur tradisi di dalam suatu budaya tertentu). (Danandjaja 1991:5).

Hasil penilitian yang dilakukan pada Sanggar Seni Tradisional Sekar Wijaya Kusuma, bahwa aktifitas pembinaan seni tradisional memjalakan fungsifungsi: religius, edukatif, peneguh integrasi sosial, hiburan, dan mata pencaharian. Dimana kegiatan yang dikembangkan sebagai upaya untuk memberdayakan masyarakat secara sosial, ekonomi dan politik, disamping menjalan fungsi pelestarian seni dan budaya tradisional. Dan yang tidak kalah penting bahwa aktifitas tersebut merupakan kegiatan pembelajaran pada masyarakat pada kontek pendidikan non-formal sebagai bagian dari penididkan sepanjang hayat. 
Berdasarkan hasil penelititan di atas, maka untuk memaksimalkan hasi pembinaan seni pada sanggar seni ntradisional perlu diterapkan suatu manajemen program yang strategis. Dengan penerapan manajemen program tersebut diharapkan seluruh aktifitas pembinaan seni pada sanggar tradisional dapa dirancang dan dilaksanakan dengan baik. Sehingga semua program dapat dievaluasi dengan baik, dan hasil kegiatannya terukur.

\section{Kegiatan Sanggar Seni Tradisional Sekar Wijaya Kusuma}

Kegiatan sanggar Sekar Wijaya Kusuma memiliki visi membangun budaya masyarakat berbasis seni tradisional. Selanjutnya, misinya adalah: (a) melestarikan keberadaan seni tradisional, dan (b) pemberdayaan masyarakat melalui program pelatihan dan pengembangan seni tradisional. Sementara itu, tujuan sanggar yaitu: (a) memberi kegiatan yang positif kepada masyaraka terutama dalam pelestarian seni tradisional, (b) merangsang masyarakat untuk berperan aktif dalam upaya pengembangan dan pemberdayaan masyarakat, (c) mereduksi dan mencegah secara total pengaruh budaya asing yang tidak sesuai dengan norma dan budaya masyarakat, (d) membangun budaya belajar sepanjang hayat (life long learning) pada masyarakat

Bagi masyarakat setempat pada awalnya kegiatan ini adalah merupakan suatu kegiatan yang hanya berfungsi untuk pelestarian budaya tradisional, dimana di dalamnya terkandung nilai-nilai tentang kesempurnaan hidup yang sifatnya sangat religius. Dalam perkembangannya seiring perubahan dan perkembangan jaman, seni tradisional tersebut berkembang menjadi seni pertunjukan yang berfungsi untuk memberi hiburan pada masyarakat. Senyampang dengan ha tersebut, bagi pelaku seni pertunjukan, ketrampilan berolah seni tradisional kemudian dikembangkan menjadi profesi alternatif, disamping mata pencaharian utama sebagai petani. Setiap malam Minggu-Pahing diadakan pentas terbuka sebagai upaya peningkatan apresiasi terhadap seni tradisional kepada masyarakat sekitar.

Peserta kegiatan pada sanggar Sekar Wijaya Kusuma rata-rata adalah remaja dan orang tua. Untuk Wayang Kulit dan Wayang Orang diikuti oleh orang tua, sedangkan remaja mengikuti jathilan dan hadrah. Adapun anak-anak mengikuti jathilan dan hadrah yang melibatkan anak sekolah di sekitar Desa Margodadi. Seluruh kelompok sanggar beranggotakan tidak kurang dari 200 orang yang tersebar di masing-masing jenis seni tradisional.

Adapun bentuk pewarisan ketrampilan berolah seni diajarkan secara turun temurun dari generasi satu ke generasi berikutnya. Sehingga dalam penyampaian pengetahuan dan ketrampilan berolah seni tradisional mengalir begitu saja tanpa didukung dengan metode-metode pelatihan dan pembelajaran yang lebih mutakhir. Hal tersebut sangat kelihatan jelas dengan belum adanya program pelatihan yang memaparkan materi, proses, tujuan dan target yang akan dicapai. Dalam perkembangannya, dengan semakin banyaknya keberadaan para akademisi seni di desa tersebut, lambat laun pembinaan dan pengembangan seni tradisional mulai dengan pendekatan pelatihan dan pembelajaran dengan menggunakan metode pelatihan yang sistematis serta dengan media pelatihan yang memanfaatkan teknologi informasi.

\section{ANALISIS KEGIATAN}

Dengan kenyataan di atas maka sanggar seni tradisional Sekar Wiaya Kusuma perlu menetapkan strategi kebijakan dalam hal pelestarian dan pengembangan seni tradisional serta upaya pemberdayaan masyarakat. Adapun upaya yang ditempuh adalah melalui analisis permasalahan yang dihadapi. Analisis pemasalahan merupakan bagian yang sangat penting dalam proses perencanaan setelah inventarisasi data. Dengan menganalisis data yang ada akan didapatkan suatu strategi dan kebijakan yang direncanakan untuk waktu yang akan datang. Perlu dilakukan suatu analis kebijakan strategis yang bertujuan untuk menyusun progam pengembangan kegiatan pelestarian dan pengembangan seni tradisional serta upaya pemberdayaan masyarakat. Sehingga akan dihasilkan konsep manajemen program yang diharapkan akan dapat menghasilkan perencanaan program yang tepat dan sesuai sasaran.

Salah satu proses dalam konsep manajemen adalah menyusun faktor penentu keberhasilan yang diawali dengan mengkaji lingkungan strategis yang meliputi kondisi, situasi, keadaan, peristiwa, dan pengaruh-pengaruh yang berasal dari dalam maupun dari luar kelompok kegiatan tersebut. Lingkungan internal dan eksternal mempunyai dampak pada kehidupan dan kinerja seluruh komponen yang terlibat pada pengembangan kegiatan, mencakup kekuatan dan kelemahan internal serta peluang dan tantangan eksternal. (Nawawi 2005 : 163)

Analisis kegiatan merupakan bagian yang sangat penting dalam proses perencanaan setelah inventarisasi data. Dengan menganalisis data yang ada akan didapatkan suatu strategi dan kebijakan yang direncanakan untuk waktu yang akan datang. Program kegiatan pada sanggar seni tradisional Sekar Wijaya Kusuma perlu dilakukan suatu analiais kegiatan untuk menyusun progam pengembangan kegiatan. Sehingga diharapkan akan didapatkan hasil perencanaan yang baik dan benar.

Analisis lingkungan strategis adalah menyusun asumsi-asumsi strategis dan mengujinya dengan visi dan misi organisasi (Sanggar Seni Tradisional Wijaya Kusuma) untuk memperoleh faktor penentu keberhasilan. Pelaksanaan analisis lingkungan strategis merupakan bagian dari komponen perencanaan strategis dan merupakan suatu proses untuk selalu menempatkan organisasi pada posisi strategis sehingga dalam perkembangannya akan selalu berada pada posisi 
yang menguntungkan. Lingkup analisis lingkungan strategis meliputi Analisis Lingkungan Internal dan Analisis Lingkungan Eksternal

\section{Identifikasi Faktor-faktor Interna}

\section{Kekuatan}

a. Ketersedian tempat untuk beraktifitas

b. Dukungan pemerintah daerah terhadap pengembangan seni tradisional

c. Sudah ada instansi yang mempunyai Tupoksi pembinaan seni tradisional

d. Kesediaan anggota untuk mendanai kegiatan secara mandiri terutama pengurus sanggar.

\section{Kelemahan}

a. Belum adanya anggaran dasar dan anggaran rumah tangga organisasi

b. Kurangnya koordinasi antar komponen organisasi

c. Peraturan organisasi tdak berlaku secara efektif

d. Belum adanya sistem penghargaan yang pasti

\section{Identifikasi Faktor-faktor Eksternal}

1. Peluang

a. Adanya dukungan dari Pengkab Sleman dan kesadaran masyarakat akan pelestarian seni tradisional

b. Adanya kebijakan Dinas Pariwisata dan Kebudayan tentang strategi pengembangan pariwisata yang berbis pada budaya tradisional

c. Masih terdapatnya ruang-ruang publik untuk melakuakn aktifitas berkesenian teruatama ssni tradisional.

d. Ketersediaan event budaya tradisional untuk pengembangan seni dan budaya.

\section{Ancaman}

a. Besarnya pengaruh seni dan budaya modern

b. Tingginya intensitas tanyang seni dan budaya modern di media masa terutama tayang televisi.

c. Kurangnya kesadaran beberapa pihak tentang arti pentingnya pelestarian seni tradsional.

d. Kurang tersedianya waktu untuk aktifitas berkesenian yang disebabkan oleh kesibukan aktifitas ekonomi mayarakat.

\section{ANALISIS STRATEGI PILIHAN}

Strategi adalah kegiatan, mekanisme, atau sistem untuk mengantisipas secara menyeluruh dan memprediksi pencapaian tujuan ke depan melalui pendekatan rasional. Strategi ini disusun dengan memadukan antara kekuatan (strength, S) dengan peluang (opportunity, O) yang dikenal sebagai strategi S-O memadukan kelemahan (weakness, W) dengan peluang (opportunity, $\boldsymbol{O}$ ) yang dikenal sebagai strategi W-O; dan memadukan kekuatan (strength, $\boldsymbol{S}$ ) dengan ancaman (threath, $\mathbf{T}$ ) yang dikenal sebagai strategi $\mathbf{S}-\mathbf{T}$.

Strategi S-O dimaksudkan sebagai upaya memaksimalkan setiap unsur kekuatan yang dimiliki untuk merebut setiap unsur peluang yang ada seoptimal mungkin, strategi W-O dimaksudkan sebagai upaya memperbaiki masing-masing unsur kelemahan agar dapat memanfaatkan seoptimal mungkin setiap unsur peluang yang ada, sedangkan strategi S-T dimaksudkan sebagai upaya untuk memaksimalkan setiap unsur kekuatan untuk menangkal dan menundukkan setiap unsur tantangan seoptimal mungkin.

Dengan demikian akan diperoleh berbagai strategi pilihan yang merupakan hasil perpaduan antar unsur kekuatan, kelemahan, dan peluang. Masing-masing strategi pilihan tersebut harus diuji kembali relevansi dan kekuatan relasinya dengan sumberdaya yang tersedia pada sanggar seni tradisional Sekar Wijaya Kusuma, sehingga kegiatan yang dilakukan benar-benar mampu memberdayan masyarakat.

\begin{tabular}{|c|c|c|}
\hline \multicolumn{3}{|c|}{ Matriks Analisis SWOT } \\
\hline Kekuatan dan Kelemah & 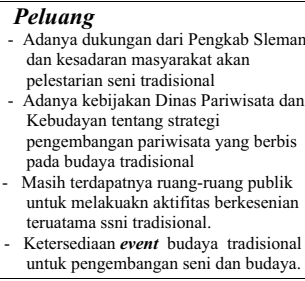 & \begin{tabular}{|l|} 
Ancaman \\
- Besarnya pengaruh seni dan budaya \\
modern \\
- Tingyinya intensitas tanyang seni dan \\
budaya modern di media masa terutama \\
tayang getivisi. \\
- Kurangnya kesadaran beberapa pihak \\
tentang arti pentingnya pelestarian seni \\
tradsional. \\
- Kurang terse dianya waktu untuk \\
aktifitab berkesenian yang disebabkan \\
oleh kesibukan aktifitias ekomi \\
mayarakat.
\end{tabular} \\
\hline $\begin{array}{l}\text { Kekuatan } \\
\text { - Ketersedian tempat untuk beraktifitas } \\
\text { - Dukungan pemerintat daarah terhadap } \\
\text { pengembangang seni tradisional } \\
\text { - Sudalad ad intsansi yang mempunyai } \\
\text { Tupoksi pembinaan seni tradisional } \\
\text { - Kesediaan anggota untuk mendanai kegiatan } \\
\text { secara mandiri terutama pengurus sanggar. }\end{array}$ & $\begin{array}{l}\text { Strategi I } \\
\text { - Mengkoordinasikan instansi } \\
\text { pemerintah terkait pemanfaatan } \\
\text { tempat aktifitas masyarakat } \\
- \text { Mengembangkan potensi pariwisata } \\
\text { berbasis seni tradisional } \\
\text { - Meningkatkan peran serta masyarakat } \\
\text { dalam event budaya tradisional }\end{array}$ & $\begin{array}{l}\text { Strategi II } \\
\text { - Penguatan terhadap budaya lokal } \\
\text { diseluruh lini pemerintahan dalam } \\
\text { upaya membendung pengaruh } \\
\text { budaya modern } \\
\text { - Upayan pemberdayaan masyarakat } \\
\text { dengan pelibatan seluruh potensi } \\
\text { masyarakat } \\
- \text { Sosialisas tentang program } \\
\text { pemberdayan masyarakat melalui } \\
\text { seni tradisionanal }\end{array}$ \\
\hline $\begin{array}{l}\text { Kelemahan } \\
\text { - Belum adanya anggaran dasar dan anggaran } \\
\text { rumant tangga organisasi } \\
\text { - Kurangnya koordinasi antar komponen } \\
\text { organisasi } \\
\text { - eraturan organisasi tdak berlaku secara } \\
\text { efektif } \\
\text { - Belum adanya sistem penghargaan yang pasti }\end{array}$ & \begin{tabular}{|l} 
Strategi III \\
- Mengkoordinasikan antara instansi \\
pemerintah dengan komopnen \\
masyarakat. \\
- Upaya pengembangan mmanajemen \\
program pemberdayaan masyarakat \\
oleh pemerintah dan kelompokm \\
masyrakat \\
- Meningkatkan sistem penghargaan \\
kepada kelompok masyarakat \\
tradisional \\
\end{tabular} & \\
\hline
\end{tabular}




\section{Rencana Manajemen dan Implementasi Program}

Dari analisis permasalahan yang telah dilakukan diatas maka perlukan rencan tindakan yang strategis adaalah sebagai berikut :

\section{Rencana Tindakan Manajemen Program}

a. Mengkoordinasikan instansi pemerintah terkait pemanfaatan tempat aktifitas masyarakat.

b. Mengembangkan potensi pariwisata berbasis seni tradisional

c. Meningkatkan peran serta masyarakat dalam event budaya tradisional

d. Penguatan terhadap budaya lokal diseluruh lini pemerintahan dalam upaya membendung pengaruh budaya modern

e. Upaya pemberdayaan masyarakat dengan pelibatan seluruh potensi masyarakat

f. Sosialisasi tentang program pemberdayaan masyarakat melalui seni tradisional

g. Mengkoordinasikan antara instansi potensi pemerintah dengan komponen masyarakat.

h. Upaya pengembangan manajemen program pemberdayaan masyarakat oleh pemerintah dan kelompok masyrakat

i. Meningkatkan sistem penghargaan kepada kelompok masyarakat tradisional

\section{Strategi Tindakan :}

a. Memberi pelatihan kepada masyarakat tentang pengembangan dan pelestarian seni tradisional

b. Memberi pelatihan tentang pengetahuan pengembangan pariwisata yang berbasis seni tradisional

c. Materi pelatihan harus dapat memberikan manfaat yang spesifik bagi masyarakat.

d. Sasaran pelatihan meliputi seluruh lapisan masyarakat secara berjenjang.

e. Meningkatkan kerja sama antar instansi pemerintah dan menumbuhkan partisipasi aktif masyarakat.

f. Meningkatkan kewaspadaan masyarakat akan pengaruh budaya modern, dan kesadaran serta kepedulian masyarakat terhadap terhadap arti pentingnya pelestarian dan pengembangan budaya tradisional.

\section{Implementasi :}

a. Materi pelatihan kepada masysrakat mengenai seni tradisional adalah: sejarah seni tradisional, manfaat seni tradisional, manajemen program latihan, manajemen pertunjukan, manajemen produksi dan manajemen pemasaran b. Mendorong otoritas pemerintah dan non pemerintah untuk mengembangkan dan melestarikan seni tradisional melalui kebijakan strategis instnsi teknis pemerintah (Dinas Pariwisata dan Kebudayaan)

c. Melakukan monitoring dan evaluasi serta memberi penghargaan terhadap proses dan hasil dari kegiatan penbembangan dan pelestarian seni tradisional yang dilakukan oleh masyarakat.

d. Proses kegiatan yang berkelanjutan dengan metode yang disepakati masyarakat.

e. Menempatkan program pengembangan dan pelestarian seni tradisional sebagai bagian yang integral dari program pembangunan lainnya.

\section{Upaya Manajemen Strategis dalam Pemberdayan Masyarakat}

Berdasarkan fakta tentang keberadaan seni tradisional di masyarakat, dan masih rendahnya kesadaran masyarakat terhadap arti pentingnya seni tradisional, maka perlu diupayakan suatu manajemen program yang strategis sebagai upaya pengembangan dan pelestarian seni tradisional dalam rangka pelaksanaan program pemberdayaan. Oleh karena itu perlu disusun suatu upaya yang strategis yang secara konseptual sebagai berikut :

a. Mendudukan masyarakat sebagai subyek pembangunan.

b. Kesinergian antara komponen masyarakat dan pemerintah sebagai inti kebijakan.

c. Proses pembangunan yang berkelanjutan.

d. Tata pemerintahan yang baik dan bersih.

Dengan konsep-konsep tersebut diharapkan mampu menciptakan suatu strategi pemberdayaan masyarakat agar secara aktif terlibat dalam proses pelatihan seni tradisioan. Adapun strategi pemberdayaan masyarakat tersebut adalah :

a. Memperkuat potensi seni tradisiona masyarakat agar dapat lebih berkembang,

b. Memfasilitasi dan menyokong potensi seni tradisiona masyarakat agar dapat lebih berkembang,

c. Menciptakan situasi dan dan kondisi dimana seni tradisiona masyarakat dapat lebih berkembangan

d. Melindungi potensi seni tradisional masyarakat agar dapat lebih berkembang. berikut: Adapun indikator keberhasilan program yang dihaparkan adalah sebagai

a. Tersedianya data dan informasi yang akurat tentang sistem pembinaan dan pengembangan seni tradisional di masyarakat

b. Meningkatnya dukungan dan komitmen selurah komponen, baik pemerintah, masyarakat, dan organisasi lain 
c. Dilibatkannya seluruh intstitusi pemerintah, masyarakat dan organisasi lain dalam program pembinaan dan pengembangan seni tradisional.

d. Terbentuknya jaringan yang saling bersinergi.

e. Tersusunnya rencana operasional yang terintegrasi, baik dan benar (Spesific, Measureble, Acievable, Reliable, Timeline)

f. Terselenggara pelaporan, monitoring, dan evaluasi secara berkala.

\section{PENUTUP}

Aktifitas kebudayaan yang berakar pada seni tradisional sesungguhnya adalah usaha pewarisan nilai dari suatu generasi kepada generasi berikutnya. Sehingga interaksi yang terjadi dalam aktifitas seni tradisional merupakan kegiatan belajar, dimana dalam aktifitas tersebut akan terjadi terjadi dialog antara kelompok masyarakat yang berada di dalam habitat kesenian tersebut. Dalam dialog dimungkinkan terjadi suatu proses identifikasi terhadap masalah-masalah yang dihadapi, sehingga kelompok masyarakat tersebut akan berusaha mencari solusi dalam rangka pemecahan masalah-masalah yang dihadapi, dan pada akhirnya secara mandiri mampu meningkatkan harkat dan martabat kelompok masyarakat tersebut.

Dalam kenyataan, belum semua instansi pemerintah, masyarakat dan kelompok lain menyadari tentang pentingnya pelestarian dan pengembangan sen tradisional, serta. seriusnya ancaman budaya modern yang tidak sesuai dengan norma dan budaya Bangsa Indonesia. Agar pembinaan seni tradisional efektif di dalam konteks pembangunan masyarakat yang lebih luas, seni tradisional tidak boleh dipisahkan dari kehidupan masyarakat, tetapi harus dipandang sebagai suatu bagian nyata dari kehidupan masyarakat.

Untuk mencapai tujuan pemberdayaan masyarakat melalui pembinaan seni tradisional diperlukan manajemen program pelatihan yang strategis. Bila in tercapai, seni tradisional dapat menjadi titik fokus untuk interaksi sosial, pelibatan masyarakat dan partisipasi berbasis luas. Hal ini dapat menjadi proses penting dalam aspek-aspek lain dari pembangunan masyarakat, seperti pembangunan sosial, pembangunan ekonomi, atau pembangunan politik.

\section{DAFTAR PUSTAKA}

Danandjaja, J. 1991. Folklor di Indonesia. Jakarta: Penerbait UI

Frans Hendra. 1975. Manajemen Mencapai Hasil. terjemahan: Managing for Result Jakarta: PT. Gramedia

Ife, J. 1997. Community Development, Australia: LONGMAN

Miftah Thoha. 1983. Perilaku Organisasi: Konsep Dasar dan Aplikasinya. Jakarta: CV. Radjawali

Nawawi, H. 2005. Manajemen Strategik: Organisasi Non Profit, Bidang Pemerintahan. Yogyakarta: Gajah Mada University Press.

\section{SENI RAKYAT DALAM DIMENSI INDUSTRIAL}

\author{
Sutiyono \\ Fakultas Bahasa dan Seni Universitas Negeri Yogyakarta
}

\section{Abstract}

This article discusses the role and position of folk art in facing industrialization era. When facing this, folk art, in terms of its presentation, is divided into two. First, folk art should surrender to the power of industrialization. It has to limit its time and space performance in which it has to be recorded in a smaller package. The social followers then only need to play the recording to be able to enjoy the performance. Second, the folk art is presented in a complete form without any reduction. The social followers, thus, prefer to its live performance in its original version. They play a role as a form of cultural resistance in facing this globalization and industrialization era.

Keywords: folk art, industrialization, and cultural resistance

\section{PENDAHULUAN}

Tidak dapat dipungkiri bahwa kehidupan seni rakyat ditopang secara penuh oleh pola budaya masyarakat agraris. Tatkala mulai dari pagi, siang hingga sore bekerja seharian di sawah dan tegalan, pada malam haringa para petani menghibur diri dengan aktivitas berkesenian. Dalam arti seni rakyat dapat memberikan kontribusi, yakni menghibur diri dan memberikan semangat kepada para petani yang suntuk bekerja di sawah. Rasa lelah yang dialaminya setiap hari, hilang dengan sendirinya ketika mereka berkumpul bersama untuk mengadakan aktivitas estetis tersebut. Bahkan aktivitas berkesenian menjadi pekerjaan kedua setelah pekerjaaan pertama dihabiskan di persawahan. Mereka menyatakan, tanpa hadirnya kesenian hidup ini terasa ada yang kosong. Demikian, begitu mengentalnya kesenian di hati para petani atau rakyat yang hidup di wilayah pedesaan, sehingga jenis seninya disebut seni rakyat. Joost Smiers (2009: 3) mengungkapkan bahwa seni menyajikan masa-masa terbaik dalam hidup kita-momen-momen harmonis, menyenangkan, menghibur, ataupun momenmomen yang menawarkan kesempatan unik untuk melakukan refleksi. Seni dipandang dapat memberikan kontribusi bagi kehidupan masyarakat di sekitarnya, karena melegakan, menghibur, mendukung aktivitas keseharian, melegitimasi acara, dan membuat romantis manusia. 